\title{
Pastoral Care and the Caring Teacher - Value Adding to Enabling Education
}

\author{
Karen Seary and Julie Willans \\ CQUniversity, Australia
}

\begin{abstract}
The concept of pastoral care to effectively meet the personal, social and academic needs of students is a complex yet under-researched matter in higher education. Similarly, under-researched and institutionally undervalued is the pivotal role that the caring teacher fulfils in imbuing pastoral care in enabling courses. Using an enabling course in a regional Australian university as the context, this article outlines the concept of pastoral care and then discusses the characteristics of the caring teacher, so fundamental to enabling education. The article draws on Motta and Bennett's (2018) pedagogies of care, namely care as recognition, care as dialogic relationality, and care as affective and embodied praxis to analyse how the students perceived and valued care in the enabling course in which they participated. Findings indicate that supportive learning environments in which caring teachers nurture their students can promote very positive interactions, and ultimately, high student satisfaction and retention.
\end{abstract}

Keywords: Enabling education; pastoral care; caring teachers; supportive learning environments; student satisfaction; retention.

\section{Overview}

Many definitions of pastoral care exist, all of which reflect the concept of care and concern for the welfare of students within a learning environment that supports their physical, social, intellectual, emotional and spiritual development. Soto (2005, p.861) explains that due to the multiple dimensionality of 'caring' and its broad variety of interpretations and beliefs, a universal definition fails to adequately represent the voices of all. Fundamentally, pastoral care relates to an educator's commitment to and proactive demonstration of support and concern for the students with whom they interact. Integral to the embodiment of pastoral care in the context of teaching is the construct of the caring teacher and the typical characteristics they display denoting them as such. In this article, the analysis of student voice data portrays that the qualities students most value in the enabling course in which they participated embodied pedagogies of care as theorised by Motta and Bennett (2018), namely: care as recognition; care as dialogic relationality; and care as affective and embodied praxis. The article commences by contextualising the study in a pre-university enabling course known as STEPS (Skills for Tertiary Education Preparatory Studies), established in 1986 at CQUniversity to enhance the multidimensional development of adult learners preparing for undergraduate studies. Literature relating to pastoral care and the caring teacher is then discussed, followed by a brief description of the methodology employed to generate and analyse student voice data. Key findings are discussed in relation to Motta and Bennett's (2018) pedagogies of care framework. The article concludes with the strong recommendation that more research about the construct of care in higher educational contexts be undertaken. Such a construct is largely trivialised and devalued in a teaching and learning environment that is persistently driven by masculinised, hegemonic practices (Motta \& Bennett, 2018), often obscuring the role of caring teachers and the importance of pastoral care.

This work is licensed under a Creative Commons Attribution 4.0 International Licence. As an open access journal, articles are free to use with proper attribution. ISSN: 2205-0795 


\section{STEPS in Context}

STEPS is a non-award, tuition-free pre-university enabling course that provides a pathway for those seeking to gain entry to higher education in Australia. It is designed for learners who do not meet the undergraduate admission requirements for university, or who need additional support to gain the knowledge, skills and confidence to undertake further study. Applicants to STEPS must be: 18 years or older within an academic year of enrolment; an Australian or New Zealand citizen; an Australian permanent resident or holder of a humanitarian visa; or a resident of Australia. Most STEPS students belong to multiple target equity groups recognised by the Commonwealth government as disadvantaged in their access to higher education. These comprise learners from a non-English speaking background; people with disabilities; people from rural and isolated areas; women in non-traditional areas of study; people from socioeconomically disadvantaged backgrounds and indigenous Australians (Department of Education, Science and Training, 2003). Offered in full time, part-time, on-campus or by distance (online) mode, the STEPS course incorporates academic communication, mathematics, computing, science, independent learning skills, study skills and library/information literacy skills. Upon successful completion of STEPS, students can apply for admission to a CQUniversity diploma or degree course through the direct entry process. Of note is that CQUniversity undergraduate students already enrolled in an undergraduate degree are also eligible to study individual STEPS units to upskill in academic writing, mathematics, science or computing, the aim being to address any underpreparedness they recognise as hampering their success in their award study.

Generally, STEPS students pursue further study because they lack the essential knowledge, skills and subsequent confidence pertinent to and required for entry to academia. In many instances, they bear deep-seated misgivings about their academic ability and chance of success in higher education, and despite showing strengths acquired from their lived experiences, many are skeptical about their ability to succeed in STEPS. For many, it represents an alien environment, one they have little knowledge of or experience with. However, the STEPS curriculum, holistic and transformative in nature, aims to address and help extinguish negative self-perceptions of self as learner, and at its heart lies transformative learning (Seary \& Willans, 2004; Willans, 2010). Through its carefully planned and tailored curriculum, students are encouraged and guided to critically reflect on and negate pre-conceived negative perceptions of themselves as learners. To this end, many STEPS lecturers provide ongoing constructive, non-judgemental feedback on students' progress, and ensure the provision of strategies, skills and knowledge that build to consolidate the foundational skills and attributes necessary for students to commence undergraduate studies. The development of independent learning skills, alongside the skills and knowledge to facilitate entry to such study allows many students to complete STEPS with a tangible sense of preparation for the next stage of formal learning. The theory of andragogy infuses the STEPS course, guaranteeing that it is purposefully and solidly grounded in the principles of adult learning (Brookfield, 1986; Cranton, 2016; Foley, 2000; Knowles; 1984). In acknowledging and building on the prior learning and life experiences of adult learners, their motivation to learn, and the need for meaningful, relevant knowledge and guidance, teachers in STEPS provide a supportive learning environment in which pastoral care can be instrumental in encouraging adult learners to more fully reach their potential.

\section{Literature Review}

There is scant literature relating to the concept of pastoral care and the caring teacher in higher education contexts. Most literature discussed in this section of the article relates to secondary school contexts but the discussions within resonate with practices adopted by many enabling educators. Pastoral care is a somewhat difficult concept to define as it is simple yet complex. Crane (1990) suggests there are widely accepted aspects by which pastoral care as a concept may be understood. He proposes that pastoral care incorporates a broad set of needs pertaining primarily to the wellbeing of students and that these needs may be categorised as intellectual and academic; physical; social, emotional and psychological; and moral and spiritual. Hamblin (1978) claims that pastoral care is not something set apart from the daily work of the educator and recommends that the pastoral effort should reflect the willingness to adapt the learning environment to meet the needs of individual students in order that all students, regardless of background or ability, are accommodated and that the realisation of success is possible for all. Similarly, Best (1988) contends that the needs of the student should provide the starting point for pastoral care and the development of structures and processes to address such needs.

Despite the ambiguity and openness of the notion of care to different interpretations (Isenbarger \& Zembylas, 2007), a more general discussion of the notion of care is important in understanding pastoral care. Baumeister and Leary's (1995) research on human interpersonal behavior suggests individuals have a basic desire to belong and interact with others in a personal and 
caring manner, and it is through these interactions that bonds are established. Oliner and Oliner (1995) claim that caring occurs when one assumes a vested interest in another's welfare and actively seeks to help them succeed. Isenbarger and Zembylas (2006) suggest that caring is a vital aspect of education and that an ethic of caring "emphasizes receptivity, relatedness and responsiveness" (p. 122). From a relational, feminist perspective, Noddings (2002) asserts that being cared for is a fundamental want for most people and suggests that while both men and women are basically guided by an ethic of care, it is women who generally provide the "natural" caring, a form of caring that does not require an ethical effort to motivate it. Noddings (1984) considers ethical caring to be dependent on appropriate contributions from both the "carer" and the "cared-for". Noddings (cited in Smith 2004) distinguishes the concepts of "caring-about" and "caring-for" by saying that "caring for" a student involves more attention. She says that what is central to care theory is that "caring about" must be seen as instrumental in establishing the conditions under which "caring for" can flourish. Noddings (cited in Smith 2004) further claims that "caring about" is empty if it does not culminate in caring relations. She suggests that caring teachers have a significant positive impact upon their students (Noddings,1992) and that they should seek to build upon the strengths that students bring to a learning context in an environment of caring, rather than through competition.

The concept of care can be manifested in many ways in an educational setting. Meyers $(2009$, p. 206) takes the stance that "students care if we care about them", and that at times, the focus should be more on students than on subject matter. Hayes (2006) emphasises that the educational learning environment needs to be welcoming and encourage a sense of belonging for students. Noddings (cited in Smith, 2002, pp.10-11) holds that education from the care perspective has four key components: modelling, dialogue, practice and confirmation, and that educators must genuinely demonstrate caring for students in their relations with them. Noddings (1984) emphasises that, as caring may be manifested in different ways, it is important that educators understand their own relationships and practice. Through student feedback, they can assess their success in their attempts to care for those they are privileged to guide. Noddings (1984) also maintains that caring develops through practice, and that reflecting on practice is essential to its growth. It can also add to a more positive experience for students and teachers alike, evidenced by Teven (2001) who found a direct correlation between positive student evaluations of courses and student references to caring teachers.

Caring teachers and caring practices are embodied in a variety of ways. Walker and Gleaves (2015) suggest that, despite conceptual and methodological differences, certain characteristics of "good teachers" exist in their exhibition of an array of practices and behaviours underpinned by what is termed a relational approach to pedagogy. Caring teaching can be defined as fostering pedagogy that exhibits the "active fostering of and maintenance of pedagogic relationships above all else, and within these, the privileging of trust, acceptance, diligence and individual attentiveness" (Walker \& Gleaves, 2015, p. 66). Caring teachers translate these into their practice whereby they respond to students in a timely manner, know their students, ensure authenticity in their dealings with students, and treat their students in a consistent manner. It may be claimed that all teachers care, but as Noddings (2002) highlights, there is a difference between caring by working hard at teaching and caring through the establishment of relationships based on trust and genuine concern. She claims that true caring is not about teachers attaining the desired results through hard work and control, but rather through developed relationships. As Hayes (2006, p.95) proposes, good relationships between staff and students hold the group together and enhance learning.

There are certain characteristics the caring teacher is said to display. Tarlow (1996) suggests these include the willingness of the educator to spend time outside of scheduled classes to assist the student in any way they can; willingness to talk often and in a relaxed manner; sensitivity to the needs of the student; and acting in the best interests of the student. Similarly, McCroskey (1992) proposes three factors that engender a perception of care: empathy, understanding and responsiveness. Students experience a sense of care when they witness an educator who seeks to understand their needs, emotions and thoughts, and in turn, responds promptly and attentively. Larsen (2015) cautions that the emotional aspect of care is challenging to describe; however, many student participants in his study were found to use words such as comfort, warmth, friendliness, safety, goodness, kindness, patience, sincerity and aura to describe the feeling of perceived care. He suggests the most meaningful relationships are those in which individuals know and understand each other. Larsen (2015) characterises a caring teacher to be one who: shares information about themselves with students; tries to come to know their students as people as well as students; is actively interested in their opinions and attitudes; takes the time to listen carefully; and responds with kindness and thoughtfulness. As Wentzel (1997) claims, students are most highly motivated to learn in an environment where they perceive they are cared for. Noddings (1992) proposes that care is best evidenced when educators cease to place their own needs and concerns as their highest priority and instead place the needs and concerns of their students first. Where there exists a positive relationship between teacher and student, the interests and strengths of the learner become a priority. Thus, successful 
pedagogical activity is founded on the existence of relationships of trust and care, a recommendation by Hayes (2006) who maintains that educators need to develop professional relations of trust with students and consider them in their entirety, not just as students. After all, to build a positive student/teacher relationship, the educator needs to take an interest in their students as individuals and exhibit behaviours that indicate they care about them as people, not just learners. They need to ensure each learner in their learning community feels connected, appreciated, accepted and integral to the community. Huber (2009, p.15) describes this holistic view as "bringing care for the whole person - hand, head and heart... into the educational equation".

Little empirical research can be found about the caring teacher in the higher education context, but this is slowly changing. Walker and Greaves (2015) point out that most scholarship pertaining to this subjective issue relates to studies in secondary school settings. However, a growing body of literature attests to the importance of creating a sense of belonging for students in higher education settings (see, for example, Hellmundt \& Baker, 2017; Kahu, 2014; Lane \& Sharp, 2014; Leach, Zepke, \& Prebble, 2006; Lisciandro \& Gibbs, 2016; Naylor, 2017; Shields, 2015; Stone \& O’Shea, 2016; Tinto, 2017; Wimpenny \& Savin-Baden, 2013), and the value of communities of care (Crawford et al., 2018). Further evidence of this notion can be found in research by Relf et al. (2017) who refer to the 'hidden curriculum' in their investigation of curriculum design within an Australian pre-university enabling program. The hidden curriculum is defined as everything involved in the teaching and learning process that is not written down in the intended curriculum (Jackson, 1968). Enabling staff in Relf et al.'s (2017) study exhibited a concern for fostering empowerment, personal development and confidence in students. Findings from focus groups established "a culture of care, empathy and support" as features of enabling programs, alongside the establishment of a "nonjudgemental, inclusive and open environment" (Relf et al., 2017, p.17) where relationships develop within a learning community. This study also found that students experienced a curriculum that was inclusive, respectful, caring, supportive, non-judgemental, equitable, encouraging, explicit and student-learning centred. The study found enabling curricula are holistic, covering not only teaching and learning but also pastoral care and support.

Certain elements are required to ensure a caring learning environment. To more fully participate, learners must feel involved in and responsible for their own learning, while safe and comfortable, emotionally, mentally and physically. They must feel cared for, that they matter. Research into enabling education by Motta and Bennett (2018) focuses on care as recognition; care as dialogic relationality; and care as affective and embodied praxis. Care as recognition entails acknowledgment of the life experiences and insight students bring to the learning environment, alongside tensions associated with exclusion and misrecognition in past schooling or employment. Care as dialogic relationality focuses on the agreement that emotion is central to learning and that empathetic teachers provide "safe spaces" in learning environments that use pedagogical practices to scaffold learning, and to help students “debunk previous experiences of self in education" (Motta \& Bennett, 2018, p. 640) that may have been negative. Care as affective and embodied praxis entails the recognition that time needs to be taken to ensure students feel welcome, valued and safe within the learning environment and that their contributions are welcome. Such femininised practices remain largely marginalised (Hebson, Earnshaw \& Marchington, 2007) within the neoliberal audit culture of the institution, yet they emerge as significant aspects in creating a sense of belonging for students participating in enabling education. Motta and Bennett (2018, p. 643) also champion the thoughtful use of teaching spaces and pedagogical practices that challenge traditional, didactic practices and "disrupt power relationships within the classroom".

\section{Methodology}

This qualitative study seeks to contribute to findings such as those of Motta and Bennett's (2018) that relate to an ethos of care underpinning the philosophies, procedures and pedagogical practices of many enabling courses. The data used were comprised of approximately 2251 end of term STEPS unit evaluations, but it is difficult to quantify the percentage of all students that this represents as much movement occurs across the terms as students continue from one term to another or withdraw from the course. Nevertheless, institutional data shows that evaluations in STEPS units are consistently completed by at least $50 \%$ of all students enrolled in one or more of the ten units. For this study, data consisted of anonymous, voluntary feedback from students enrolled in any of the 11 STEPS units during the period Term 12018 to Term 3 2018-19. Data were generated via institutional, standardised unit evaluations, completed by students online over the last five weeks of terms one, two and three. Alongside seven standardised questions about satisfaction with the unit, timely and useful feedback, easily navigable learning platforms and the adequacy of resources, students were invited to comment on what they considered to be the 'best aspects' of the STEPS unit(s) in which they were enrolled. Students were also asked to suggest improvements to these units. Acknowledgement is made at this point regarding the limitations of this hegemonic method of generating data that purports to be representative of 
the student voice. However, it is hoped that the anonymous and voluntary nature of the feedback may somewhat assuage this shortcoming.

Thematic analysis was used to sort data and establish commonalities, following a method subscribed to by Vaismoradi, Jones, Turunen and Snelgrove (2016). This entailed working through the stages of initialization; construction; rectification and finalization. The initialization phase allowed for the researchers' immersion in the data, with constant reading and re-reading of the students' comments. This enabled a rudimentary assembling of recurring aspects referred to by students with regards to examples of care, compassion and consideration they experienced in STEPS. To further reduce the data, coding was used to convert the "raw data to higher-level insights or abstractions" (Vaismoradi et al., 2016, p. 104). From this, comparisons and contrasts in the initial findings were identified, but in an iterative way, data were constantly revisited and interrogated to glean different aspects. During the construction phase, the codes and their diverse meanings were reflected upon, with labelling, translating and transliterating, and defining and describing undertaken. During the rectification phase, it was necessary to step back from the data and exercise prudence about possible forecasts regarding data findings. Checking and confirming was thus necessary, accompanied by both immersion and distancing, and relating themes to established knowledge (Vaismoradi et al, 2016). This was intended to permit the relay of the student voice in an authentic, holistic way.

Motta and Bennett's (2018) pedagogies of care was then used to further explore the concept in terms of its relevance in analysing the student experience of enabling education. An ethos of care in enabling contexts constitutes an emergent philosophy of education and feminised politics of knowledge that is co-created by enabling educators and their students, and it exists in, against and beyond hegemonic, masculinised renditions of neo-liberalised, care-less higher education. Motta and Bennett's (2018) categorisation of care as recognition, care as dialogic relationality, and care as affective and embodied praxis are thus used as an analytic tool to gain greater insight into how students recognise and describe the importance of pastoral care and the caring teacher in STEPS. Such insight can legitimately demonstrate the importance of learning environments that foreground the importance of care.

\section{Findings and Discussion}

\section{Care as Recognition}

Care as recognition relates to acknowledgement of life experiences, competencies and insights each student brings to the learning environment and the value placed on these by teaching staff and those who work in the enabling context (Motta \& Bennett, 2018). In this study, it was found that students appreciated being made to feel comfortable in the learning environment, evidenced by evaluation responses relaying that their lack of knowledge about certain tasks was catered to by lecturers. As one student wrote:

The best part of this unit would have to be the way we are taught slowly about our literacy skills and not made to feel dumb if they are not at the same rate as everybody else; while another similarly shared: I do love how easy it is to communicate with the staff and how friendly and informative they are even if it is a silly query.

Students also valued opportunities to build on their prior skills to enhance future opportunities. As one student shared:

I feel like I have picked up maths again very easily and found that I actually learnt more than I did when I was in high school. I have now mastered long division and feel quite proud of myself for this.

Another student made the link between new and prior learning and being encouraged to reflect on this: "I feel as though I learnt so much from this unit, it retaught me things I had completely forgotten about and allowed me to implement critical thinking in my life". Many students applauded the lecturer's encouragement to use learning tools with applicability not only to their student lives, but application to other life roles. This was evident in comments such as:

It did not take long for me to see that the skills being taught in PSU have dramatic real-life application... So I have been budged from my bias and appreciate the benefits the skills I have been taught in this unit have on my current and future study.

Other students valued the ways lecturers acknowledged their students' life experiences and uniqueness:

All the assessments have encouraged my learning and allowed me to grow not only as a student, but as a person too; I enjoyed and learnt valuable life skills that are required at university and what is expected to balance my social, work and university life; 
I like the parts that explain our different learning styles... it's been very helpful for my learning and my everyday life...I find that I can use it to help me better myself in all aspects of Uni life and home life; and, the improvement of both my academic and personal life from learning how to study was quite extensive.

Other students appreciated teachers using pedagogical practices that encouraged development of the "whole student":

I learnt strategies that will stay with me for a life time ... I have over-come great obstacles that would have been a hindrance on moving forward and into my future studies. PLU has helped me mentally, physically and emotionally.

It was found that students appreciated the comprehensible language used by lecturers and pedagogical activities that did not assume unrealistic levels of prior learning. As one student wrote: "I consider that the best aspects of the unit were how the different programs were presented, simple, concise and easy for us to understand and learn new commands and improve the ones we already know". There were others who commented similarly, being specifically appreciative of lecturers who recognised unique needs of their students:

I was concerned going into this unit at what level my skills were, quickly though and from the positive and timely feedback from my support lecturer, my confidence and abilities have improved substantially; and, the course content was constructed in a way that it moved with us without being out of touch of what we could achieve. It was achievable and felt like it was at a university standard which raised my confidence.

A caring teacher is one who will ensure their classroom is a safe, enjoyable and engaging environment, who plans lessons thoughtfully and delivers content in an energetic and enthusiastic manner while encouraging engagement of all learners. Students were found to appreciate teaching staff who did this, taking time to recognise and cater for various skill levels. As one student wrote:

I have a great teacher who explains each topic differently to each person who does not understand. She also takes the time to make sure each person understands the topics and follows up on how we are all going. This is a major aspect to me in making sure myself and everyone passes this unit.

Students were found to express a strong sense of belonging, so important in enabling education classrooms and indeed in higher education contexts. Given the broad representation of students from various equity groups in enabling courses, welcoming classrooms and empathetic teachers are pivotal in creating a sense of belonging for students from such diverse backgrounds and a classroom environment in which diversity is valued and can be expressed. STEPS students were clearly appreciative of this:

Honestly, I enjoyed every bit of the unit. I'm glad I've learnt a lot of new interesting facts and gained knowledge ... There was always something funny or interesting in each lecture and this helped me engage with lecturer as a distant student... this helped me feel more at home; Another great aspect was that X made sure the whole class was involved. We all spoke out our own opinions and the class was a very warm environment; The best aspects of this unit was being able to be in the classroom learning, therefore if there were any questions or if we were interested in particular things we could ask the lecturer; I think the best aspects of this unit is the fact that you can have large discussions on political issues in the classroom. It makes for an entertaining lecture but also helps broaden your mind.

Other comments reveal students' appreciation for elements that lecturers incorporated to create a relaxed learning environment:

The unit made me feel calm about entering in the unfamiliar uni world; As a student who struggled at times in this unit, I would like to say that our lecturer was outstanding and her calm patient and lovely positive personality along with encouragement and never-ending assistance always kept me believing that I could succeed.

Some students alluded to how previous feelings of disorientation were dispelled through their participation and encouragement in supportive learning environments:

I'm studying via distance and not once did I feel lost or feel like I had no one to turn to. All lectures (sic) or support lecturers gave copious amounts of support throughout the unit with quick replies to emails regarding questions and outstanding feedback on our tests which personally helped myself learn a lot.

Self-reflective activities encouraged by caring teachers as a way to help students deconstruct, critique and change some ideas about themselves as a learner were valued by students, evidenced in the following comments: 
This subject is great in changing your view on how to perceive things around you and potentially improving the use of positivity in your life; This unit gives the students tools to deal with lifes (sic) troubles, relationships and how to be at their best; PSU has not only helped me build my confidence in my own ability but it has shown me that anything is possible with persistence breaking tasks down into more manageable sections; This unit has helped me more than I could of even imagined. I found the unit to be very helpful and valuable for future life whether it be in undergrad studies or work life in general; and, after being out of the formal learning environment for quite some time this unit opened my mind to areas I didn't know were there.

Other pedagogical activities used by teachers showed how they acknowledged each student's worth, encouraging them to reflect more deeply on broader social aspects. As one student revealed: "The outcome of the online tests, my thoughts, were, it is OK to be who you are. Not only on social status, [but] a deeper understanding of self and [this] brings new life to social status".

\section{Care as Dialogic Relationality}

Care as dialogic relationality focuses on the premise that emotion is central to learning (Motta \& Bennett, 2018), and that empathetic teachers provide "safe spaces" in learning environments using pedagogical practices to scaffold learning and help students "debunk previous experiences of self in education" (p. 640) of a negative nature. In the review of student voice data in this research, the importance of this was evident in the range of emotion expressed by students as they reflected on their time in STEPS:

I hold back ... for fear of failing terribly... and looking back I'm able to see why I failed at the essays I wrote during that time. This has been an incredible learning experience for me; the templates and study resources have given me a lot of confidence to really push the limits of brainstorming; I was terrified when I first started this subject but now very well enjoy it; I entered the course with much fear and believed it to be my greatest weakness, leaving it I know it to be a strength.

Another student shared:

I was really scared about doing my first essay but after the lectures and advice from my teacher, I have managed to improve, and I am not so worried now; while another student said: I felt scared to start the course but really lovely, the lectures and welcomes each week, as it made everything so clear.

And in alluding to the value of pastoral support from STEPS staff and the impact on emotion, another shared that: "The unit was well supported by staff and I never felt like I was 'alone', which was a big fear of mine heading into online study".

Students were found to be grateful when the range of their emotions was acknowledged and valued by their teachers. As one student relayed:

I appreciated that the lecturer was aware and sensitive to the fact that this unit could be difficult to process and that as a student I was supported in my learning but my emotional safety was considered and therefore this key element was not overlooked. Another said: It is overwhelming (for the likes of myself) to go back into this environment of learning, and I could so easily have been negative in this, but for the encouragement... the quality of the assistance, the manner and courtesy, kindness and patience.

Other students expressed satisfaction regarding the care shown by lecturers:

Without the feedback from my lecturer and the explanations of how and why things are done on a computer I would not have gotten this far feeling as good as I do about the work I am doing in this course.

Students also appreciated having their lives outside education acknowledged by their teacher and the acquisition of pragmatic as well as technical and academic skills to assist students with their multi-faceted lives. This was evident in various student comments:

The best part of the unit for me was focusing on time management and stress. As an adult learner with work, kids, husband and study, it's great to learn how to tackle these things before jumping into a degree; The subject matter, I have found I am including aspects of what I have learnt into my daily life; I was able to apply every bit of our learning through both Moodle, Student Guide and lectures to my everyday life and routines.

Students were also found to be highly appreciative of empathetic teachers who paid attention to student needs, encouraging them to explore and develop their own potential. This was evidenced by the following comments: 
The care of the lecturers to help to keep moving. I have seen this a lot over my course of STEPS. Having people check on you even if not needed makes you feel they care about your learning; I have a great teacher who ... takes the time to make sure each person understands the topics and follows up on how we are all going.; I am not a math person at all but with X's encouragement as well as her relaxed and down to earth teaching style, I have achieved far better results than I ever thought I would; I have learned so much in a very positive and supportive environment. I am very grateful to my lecturer for the time and effort that she took with me; I found this course absolutely unreal. I'm studying via distance and not once did I feel lost or feel like I had no one to turn to. All lecturers or support lecturers gave copious amounts of support throughout the unit with quick replies to emails; There was always a smile, a helping hand, and a feeling from her that we mattered to her as people, not just students. $\mathrm{X}$ is another lecturer who just exudes passion for her subject area, meaning you can't help but be drawn in.

\title{
Care as Affective and Embodied Praxis
}

Care as affective and embodied praxis entails recognition that time needs to be taken to ensure students feel welcome, valued and safe within learning environments and that their contributions are encouraged. There is an understanding by teachers that student engagement and participation may not always be consistent with imposed institutional time frames. As Motta and Bennett (2018) maintain, such instances of femininised practice generally remain invisible within the neoliberal audit culture of the institution, yet they emerge as significant elements in creating a sense of belonging in enabling education. Findings in this study of students' unit(s) evaluations attest to this:

\begin{abstract}
I struggled through it but I did! I could not have done without the support of X, support lecturer. My health is an issue at the moment and I had to request extensions which was given without hesitation; Having an incredibly busy work schedule this term, and then some unexpected illness, as well as some personal issues come up during the term, it was only X that kept me enrolled in this unit. When I was not able to make it to class she was always happy to sit with me and work through the problems I had. She made the class laugh and feel like it was okay to NOT be okay; At the start of the term I was genuinely daunted by the thought of returning to maths, something that is not where my natural talents lie. And at the end of the term, literally during my maths exam as I looked through it in perusal time, I remember thinking 'yes, I've got this!' and ENJOYING it! That's X's superpower. She can take something that scares you and then shows you how you can master it. She is the best thing about this uni; $\mathrm{X}$ ensured that we did not forget about deadlines, and he delivered that message often to ensure we didn't incur late penalties. Loved this class - I only got $18 \%$ for high school mathematics; Although I was not able to attend any lessons, X made sure that I wasn't left behind.
\end{abstract}

Some students indicated their gratitude for teachers who provided the opportunity to repeat STEPS units. As one student confided:

It's my second time around doing this unit but I focused all my time on maths and chemistry last time. I learnt a lot about myself and identified my weaknesses and think I am 100x better prepared to complete a degree. My main aspect I learned was to be honest to myself, so thanks.

Others were appreciative of how concerns related to a long absence from formal schooling were allayed by the teacher's encouragement:

\footnotetext{
Although being 42 years of age and not knowing anything about most of the content taught to me I was encouraged to move on and after the final exam I was on top of the moon; As someone who is 32 and has not been to school for 15 years this unit was very rewarding. I will start my course with much more confidence than I had before I completed the unit.
}

Others were happy with the consideration and encouragement they received from their teachers: "I struggled so much with my work life vs study, but the lecturers were so supportive and helpful; and X was understanding and empathetic in regard to some issues at home, and I cannot express how thankful I am". Other students appreciated the efforts of teachers who gave exceptional support: " $\mathrm{X}$ was so supportive and went above and beyond what I would have expected ... including evening and weekend calls and juggling as best she could to make sure she was there for me to answer my questions".

\section{Conclusion}

Pastoral care and caring teachers affect the environment in which students in enabling courses and the broader context of higher education learn and are integral to student satisfaction and success. Caring teachers create learning environments in which students who may be hampered by past negative educational experiences are given 'safe opportunities' to debunk deficit notions about themselves as learners. Using the student voice in this article to identify elements that students identified as 'best' in their unit(s) of study has been shown to correlate closely with the elements of a 'pedagogy of care' identified by Motta and 
Bennett (2018). This article has demonstrated how pastoral care and caring teachers in STEPS purposefully build caring relationships with students in learning environments where good teaching is not reduced to technique only. As Palmer (1998, p. 10) says "reduce teaching to the intellectual, and it becomes a cold abstraction; reduce it to the emotions, and it becomes narcissistic; reduce it to the spiritual, and it loses its anchor to the world". Caring teaching is underpinned by a relational approach to pedagogy that subsumes the privileging of trust, acceptance, diligence and individual attentiveness (Walker \& Greaves, 2015, p.65), and many enabling educators enact such caring in their classrooms. As enabling educators, it is vital that more research in this important area is undertaken and shared, the aim being to champion the importance of relational aspects of enabling education. This article, in some small way, hopes to add to the limited body of research about the pastoral care and the caring teacher in enabling and higher education contexts and urges like-minded educators to add their voices to this important dialogue.

\section{References}

Baumeister, R.F., \& Leary, M.R. (1995). The need to belong: Desire for interpersonal attachments as a fundamental human motivation. Psychological Bulletin, 117(3), 497-529. https://psycnet.apa.org/doi/10.1037/0033-2909.117.3.497

Best, R. (1988). Care \& Control: Are we getting it right? Pastoral Care in Education, 6(2), 2-9.

Brookfield, S. (1986). Understanding and facilitating adult learning. San Francisco: Jossey-Bass.

Crane, P. A. (1990). An examination of the pastoral needs of students and the needs of their teachers as providers of pastoral care. https://ro.ecu.edu.au/theses/1115

Cranton, P. (2016). Understanding and promoting transformative learning: A guide to theory and practice, ( $3^{\text {rd }}$ ed.). Stylus Publishing.

Crawford, N., Olds, A., Lisciandro, J., Jaceglav, M., Westacott, M., \& Osenieks, L. (2018). Emotional labour demands in enabling education: A qualitative exploration of the unique challenges and protective factors. Student Success, 9(1), 2333. https://doi.org/10.5204/ssj.v9i1.430

Department of Education, Science and Training (2003). Our universities - backing Australia's future. https://www.voced.edu.au/content/ngv\%3A38781

Foley, G. (2000). Understanding adult education and training, ( $2^{\text {nd }}$ ed.). Allen \& Unwin.

Hamblin, D. (1978). The teacher and pastoral care. Basil Blackwell.

Hayes, A. (2006). Teaching adults: The essential FE toolkit series. Continuum International Publishing Group.

Hebson, G., Earnshaw, J., \& Marchington, L. (2007). Too emotional to be capable? The changing nature of emotion work in definitions of 'capable teaching'. Journal of Education Policy, 22(6), 657-694. https://doi.org/10.1080/02680930701625312

Hellmundt, S., \& Baker, D. (2017). Encouraging engagement in enabling programs: The student's perspective, Student Success, 8(1), 25-33. https://doi.org/10.5204/ssj.v8i1.357

Huber, M.J. (2009). Caring for students: Pedagogy and professionalism in an age of anxiety, Emotion, space and society, 3(2), 71-79. https://doi.org/10.1016/j.emospa.2009.06.002

Isenbarger, L., \& Zembylas, M. (2006). The emotional labour of caring in teaching. Teaching and teacher education, 22(1), 120-134. https://psycnet.apa.org/doi/10.1016/j.tate.2005.07.002

Jackson, P.W. (1968). Life in classrooms. Holt Rinehart and Winston.

Kahu, E. R., Stephens, C., Leach, L. \& Zepke, N. (2014). Linking academic emotions and student engagement: mature-aged distance students' transition to university, Journal of Further and Higher Education, 39(4),481-497. https://doi.org/10.1080/0309877X.2014.895305

Knowles, M. S., \& Associates. (1984). Andragogy in action: applying modern principles of adult learning. Jossey-Bass

Lane, J. M., \& Sharp, S. (2014). Pathways to success: Evaluating the use of "enabling pedagogies" in a university transition course. GSTF Journal on Education, 2(1), 66-73. http://ro.ecu.edu.au/ecuworkspost2013/628/

Larsen, A.S. (2015). Who cares? Developing a pedagogy of caring in higher education (Doctoral dissertation) Utah State University, United States. 4287. https://digitalcommons.usu.edu/etd/4287

Leach, L., Zepke, N., \& Prebble, T. (2006). Now you have got them, how do you keep them? New Zealand Journal of Educational Studies, 41(1), 113-132.

Lisciandro, J., \& Gibbs, G. (2016). "OnTrack" to university: Understanding mechanisms of student retention in an Australian pre-university enabling program, Australian Journal of Adult Learning, 56(2), 198-224.

McCroskey, J.C. (1992). An introduction to communication in the classroom. Urges International Group.

Motta, S., \& Bennett, A. (2018). Pedagogies of care, care-full epistemological practice and 'other' caring subjectivities in enabling education, Teaching in Higher Education, 23(5), 631-646. https://doi.org/10.1080/13562517.2018.1465911

Meyers, S. (2009). Do your students care whether you care about them? College Teaching, 57(4), 205-210. 
Naylor, R. (2017). First year student conceptions of success: What really matters? Student Success, 8(2), 9-19. https://doi.org/10.5204/ssj.v8i2.377

Noddings, N. (1984). Caring: A feminine approach to ethics and mora education. University of California Press.

Noddings, N. (1992). The challenge to care in schools: An alternative approach to education. Teachers College Press.

Noddings, N. (2002). Starting at home: Caring and social policy. University of California Press.

Oliner, P., \& Oliner, S. (1995). Toward a caring society. Praeger Westport.

Palmer, P. J. (1998). The courage to teach: Exploring the inner landscape of a teacher's life. Jossey-Bass.

Relf, B., Hodges, B., Crawford, N., O'Rourke, J., Sharp, S., Hodges, B., Shah, M., \& Barnes, R., (2017). Lighting the path(way): Articulating curriculum design principles for open access Enabling programs, Australian Government Office for Learning and Teaching. https://ltr.edu.au/resources/SD15-5063_NEWC_Relf_Final\%20Report_2017.pdf

Seary, K., \& Willans, J (2004) It's more than just academic essays and rules of mathematics: Travelling the road with heroes on the STEPS journey as they convert the milestones of their learning journey into signposts for their future. Australian Journal of Adult Learning, 44(3), 306-326.

Shields, S. (2015). 'My work is bleeding': Exploring students' emotional responses to first-year assignment feedback, Teaching in Higher Education, 20(6), 614-624. https://doi.org/10.1080/13562517.2015.1052786

Smith, M.K. (2004). Nel Noddings explained. http://everything.explained.today/Nel_Noddings/

Soto, N.E. (2005). Caring and relationships: Developing a pedagogy of caring. Villanova Law Review, 50(4), 859-863, http://digitalcommons.law.villanova.edu/vlr/vol50/iss4/11

Stone, C., \& O'Shea, S. (2016). Older, online and first: Recommendations for retention and success. Australasian Journal of Educational Technology, 35(1), 57-69. https://doi.org/10.14742/ajet.3913

Teven, J. J. (2001). The relationships among teacher characteristics and a perceived caring. Communication Education, 50(2), 159-169. https://doi.org/10.1080/03634520109379241

Tinto, V. (2017). Reflections on Student Persistence. Student Success, 8(2), 1-8. https://doi.org/10.5204/ssj.v8i2.376

Vaismoradi, M., Jones, J., Turunen, H., \& Snelgrove, S. (2016). Theme development in qualitative content analysis and thematic analysis. Journal of Nursing Education and Practice, 6(5), 100-110. https://doi.org/10.5430/jnep.v6n5p100

Walker, C., \& Gleaves, A. (2015). Constructing the caring higher education teacher: A theoretical framework. Teaching and Teacher Education, 54, 65-76. http://dx.doi.org/10.1016/j.tate.2015.11.013

Wentzel, K.R. (1997). Student motivation in middle school: The role of perceived pedagogical caring. Journal of Education Psychology, 89(3), 411-419. https://psycnet.apa.org/doi/10.1037/0022-0663.89.3.411

Willans, J. (2010). Navigating personal change: transforming perceptions of self as learner. (Doctoral Thesis) CQUniversity, Australia.

Wimpenny, K., \& Savin-Baden, M. (2013). Alienation, agency and authenticity: a synthesis of the literature on student engagement, Teaching in Higher Education, 18(3), 311-326. https://doi.org/10.1080/13562517.2012.725223

Zembylas, M. (2007). Emotional ecology: The intersection of emotional knowledge and pedagogical content knowledge in teaching. Teaching and Teacher Education, 23(4), 355-367. https://doi.org/10.1016/j.tate.2006.12.002

\section{Please cite this article as:}

Seary, K. \& Willans, J. (2020). Pastoral care and the caring teacher - value adding to enabling education. Student Success, 11(1), 12-21. https://doi.org/10.5204/ssj.v11i1.1403

This article has been peer reviewed and accepted for publication in Student Success. Please see the Editorial Policies under the 'About' section of the Journal website for further information.

Student Success: A journal exploring the experiences of students in tertiary education

(c) (1) This work is licensed under a Creative Commons Attribution 4.0 International Licence. As an open access journal, articles are free to use with proper attribution. ISSN: 2205-0795 